\title{
Low Usutu virus seroprevalence in four zoological gardens in central Europe
}

\author{
Nicola Buchebner ${ }^{1,7}$, Wolfgang Zenker ${ }^{2,8}$, Christian Wenker ${ }^{3}$, Hanspeter W Steinmetz ${ }^{4,9}$, Endre Sós ${ }^{5}$, \\ Helga Lussy ${ }^{1}$ and Norbert Nowotny ${ }^{1,6^{*}}$
}

\begin{abstract}
Background: Usutu virus (USUV), a mosquito-borne flavivirus of the Japanese encephalitis virus antigenic group, caused bird die-offs in Austria, Hungary and Switzerland between 2001 and 2009. While the zoological gardens of Vienna and Zurich recorded USUV-associated mortality in different species of birds during this period, incidences in Budapest were limited to areas outside the zoo, and in the greater Basel area avian mortality due to USUV infection was not observed at all. The objectives of this investigation were to gain insight into USUV infection dynamics in captive birds in zoos with varying degrees of virus exposure and to study differences in susceptibility to USUV of different species of birds.
\end{abstract}

Results: 372 bird sera were collected between October 2006 and August 2007. The samples were tested in parallel by hemagglutination inhibition (HI) and 90\% plaque reduction neutralization tests (PRNT-90). 8.75\%, 5.3\% and 6.59\% of birds in the zoos of Vienna, Zurich and Basel, respectively, showed USUV-specific antibodies by PRNT-90. No antibodies to USUV were detected in birds of the Budapest zoo. The order Strigiformes (owls) exhibited the highest USUV-seroprevalence, compared to other orders of birds.

Conclusions: USUV seems not to pose an imminent threat to zoo bird populations in central Europe at the moment. Depending on a variety of especially environmental factors, however, this may change at any time in the (near) future, as experienced with West Nile virus (WNV). It is therefore strongly suggested to continue with combined WNV and USUV surveillance activities in affected areas.

\section{Background}

Usutu virus (USUV) is a mosquito-borne flavivirus (family Flaviviridae) of the Japanese encephalitis virus antigenic group. It was first isolated from mosquitoes in South Africa in 1959 [1] and named after a river in Swaziland. The virus had never been associated with fatal disease in animals or humans. In summer 2001, however, USUV emerged in and around Vienna, Austria, causing mortality among wild birds, particularly Eurasian blackbirds (Turdus merula) [2]. The virus continued to cause avian deaths in Austria during subsequent years $[3,4]$, extending its range of circulation to other adjacent Austrian federal states. USUV-associated bird die-offs were also recorded among wild and zoo birds in neigh-

\footnotetext{
* Correspondence: norbert.nowotny@vetmeduni.ac.at

${ }^{1}$ Viral Zoonoses, Emerging and Vector-Borne Infections Group, Institute of

Virology, University of Veterinary Medicine Vienna, Vienna, Austria

${ }^{6}$ Department of Microbiology and Immunology, College of Medicine and

Health Sciences, Sultan Qaboos University, Muscat, Oman

Full list of author information is available at the end of the article
}

bouring countries: in Hungary, starting in 2005 [5], in Italy from 2006 onwards [6], in Switzerland also since 2006 [7], in Germany since 2011 [8], and in the Czech Republic also since 2011 [9]. A recently conducted retrospective analysis of archived tissue samples originating from a bird die-off in the Tuscany region (Italy) in 1996, however, revealed the presence of USUV in Europe long before 2001 [10]. In 2009, two human cases of severe neuroinvasive USUV infections were reported from Italy [11,12]; both patients, however, had suffered from severe comorbidities.

Birds kept in zoological gardens have frequently been victims of USUV infection: one of the first outbreaks of USUV associated bird mortality in Europe was recorded in 2001 in the Vienna zoo, where five great grey owls (Strix nebulosa) succumbed to the infection [2]. In summer 2006, an USUV associated bird die-off occurred in the Zurich zoo [7] and its adjacencies. The involved birds were members of the orders Passeriformes (blackbirds and sparrows) and Strigiformes (owls). Mortality
C Biomed Central

(c) 2013 Buchebner et al.; licensee BioMed Central Ltd. This is an Open Access article distributed under the terms of the Creative Commons Attribution License (http://creativecommons.org/licenses/by/2.0), which permits unrestricted use, distribution, and reproduction in any medium, provided the original work is properly cited. 
was also recorded in captive owls in Northern Italy between 2006 and 2008 [6]. No obvious USUV associated bird mortality was observed in the Basel zoo and in the Budapest zoo, although in and around the city of Budapest a number of Eurasian blackbirds succumbed due to USUV infection [5].

This study's objectives were i) to test several species of birds, kept in four different zoological gardens in three countries, for the presence of USUV-specific antibodies; two of the selected zoos (Vienna and Zurich) had experienced USUV associated bird mortalities, while the other two (Basel and Budapest) did not report clinical USUV cases; ii) to compare the USUV antibody prevalence in the four zoological gardens; iii) to identify bird species with a higher susceptibility to USUV infection; and iv) to compare a hemagglutination inhibition (HI) test with a plaque reduction neutralization test 90\% (PRNT-90) for the detection of USUV antibodies.

\section{Results}

\section{$\mathrm{HI}$ test}

A total of 96 out of $372(25.8 \%)$ sera showed HA inhibition against USUV antigen in the HI test, 43 out of 132 (32.58\%) sera from Zurich, 40 out of 91 (43.96\%) from Basel, 11 out of 80 (13.75\%) from Vienna, and only 2 out of 68 (2.94\%) from Budapest. The titers ranged from $1: 20$ to $1: 2560$ with an arithmetic mean of $1: 142.5$.

\section{PRNT-90}

In contrast to the $\mathrm{HI}$ test results, only 20 out of 372 birds tested positive for USUV-specific antibodies by PRNT-90. Seven positives were detected in Zurich (5.30\%) and Vienna (8.75\%), respectively, and 6 in Basel (6.59\%). The sera obtained from birds in the Budapest zoo proved all USUV antibody negative in PRNT-90. The PRNT titers ranged from 1:20 to 1:640 with an arithmetic mean of 1:143 (Table 1). The 20 sera positive by PRNT-90 USUV were re-tested by a West Nile virus (WNV) PRNT-90; only the two sera with USUV PRNT titers of 1:640 reacted positive against WNV, each with a titer of $1: 20$.

\section{Comparison of $\mathrm{HI}$ and PRNT results}

Nineteen out of 20 PRNT positive sera were also positive by $\mathrm{HI}$ test. On the other hand, however, only 19 out of 96 HI positive sera were confirmed by PRNT. All further results refer to the PRNT-90 titers.

\section{Zurich zoo}

In Zurich, USUV-specific antibodies were detected in one marabou stork (Leptoptilos crumeriiferus) with a titer of 1:20, one ruddy shellduck (Tadorna ferruginea) and one red-breasted goose (Branta ruficollis), each with a titer of 1:80, one Humboldt penguin (Spheniscus humboldti) and one laughing kookaburra (Dacelo novaeguineae), both with a titer of 1:160, one steamer duck (Tachyeres pteneres) and one domestic chicken (Gallus gallus domesticus), each with a titer of 1:640.

\section{Basel zoo}

All 6 positive samples from the Basel zoo originated from greater flamingos (Phoenicopterus ruber). Their titers ranged from 1:40 to 1:160 with an arithmetic mean of 1:93.3.

\section{Vienna zoo}

In Vienna, antibodies were found in one snowy owl (Bubo scandiacus) showing a titer of 1:40, two ural owls (Strix uralensis) having titers of 1:40 and 1:80, respectively, one white stork (Ciconia ciconia) and one Egyptian vulture (Neophron percnopterus), each with a titer of 1:80, and two Eurasian eagle owls (Bubo bubo) with titers of $1: 40$ and $1: 160$, respectively.

\section{Budapest zoo}

No USUV PRNT positive sample was detected in the Budapest zoo. The results of the study are summarized in Table 1.

\section{Discussion}

Birds in zoological gardens seem to be preferred primary targets of emerging mosquito-borne flaviviruses, as it was observed for USUV in the zoos of Vienna [2], Zurich [7], and in a big collection of owls in Milan [6]; also, one of the first recorded WNV outbreaks in America occurred in a zoo [13]. Zoo veterinarians exclude the possibility of importation of infected birds to the zoos due to strict quarantine procedures applied. Thus, two possible explanations for these observations remain: i) the wide variety of avian species kept in zoos with some being vulnerable to a newly introduced mosquito-borne virus, and ii) the awareness of bird mortality is close to $100 \%$ in the setting of a zoological garden, while in the wild avian deaths are only recognized in case of mass die-offs.

Besides the first reports on the emergence of USUV in the zoos of the different countries no follow-up studies were performed. The goal of this study was therefore to investigate the USUV antibody prevalence in a variety of avian species in the zoos of Vienna, Zurich, Budapest and Basel, whereas in the zoos of Vienna and Zurich USUV-associated bird mortality had been observed, while no USUV cases were reported from the zoos in Basel and Budapest (but a few cases were identified in the greater Budapest city area).

A study that involves drawing blood from mostly very valuable species of birds is subject to restrictions. The animal ethics committees of the four zoological gardens involved only approved blood draws on two occasions: i) 
Table 1 Summary of the study results

\begin{tabular}{|c|c|c|c|c|c|c|c|c|c|c|c|c|}
\hline \multirow[t]{2}{*}{ Order } & \multirow[t]{2}{*}{ Family } & \multirow[t]{2}{*}{ Genus } & \multirow{2}{*}{$\begin{array}{l}\text { Species } \\
\text { (English name) }\end{array}$} & \multirow{2}{*}{$\begin{array}{l}\text { Species } \\
\text { (Latin name) }\end{array}$} & \multirow{2}{*}{$\begin{array}{l}\text { Number } \\
\text { tested }\end{array}$} & \multicolumn{7}{|c|}{ PRNT antibody titers to USUV } \\
\hline & & & & & & $\begin{array}{l}<20 \\
\text { neg }\end{array}$ & 20 & 40 & 80 & 160 & 320 & 640 \\
\hline Rheiformes & Rheidae & Rhea & Greater Rhea & Rhea americana & 1 & 1 & 0 & 0 & 0 & 0 & 0 & 0 \\
\hline Casuariiformes & Casuariidae & Casuarius & $\begin{array}{l}\text { Double-wattled } \\
\text { Cassowary }\end{array}$ & Casuarius casuarius & 1 & 1 & 0 & 0 & 0 & 0 & 0 & 0 \\
\hline \multirow[t]{2}{*}{ Sphenisciformes } & Spheniscidae & Spheniscus & $\begin{array}{l}\text { Humboldt } \\
\text { Penguin }\end{array}$ & $\begin{array}{l}\text { Spheniscus } \\
\text { humboldti }\end{array}$ & 19 & 18 & 0 & 0 & 0 & $1^{b}$ & 0 & 0 \\
\hline & & & $\begin{array}{l}\text { Black-footed } \\
\text { Penguin }\end{array}$ & Spheniscus demersus & 1 & 1 & 0 & 0 & 0 & 0 & 0 & 0 \\
\hline \multirow[t]{2}{*}{ Pelecaniformes } & Pelecanidae & Pelecanus & Dalmatian Pelecan & Pelecanus crispus & 5 & 5 & 0 & 0 & 0 & 0 & 0 & 0 \\
\hline & & & White Pelecan & $\begin{array}{l}\text { Pelecanus } \\
\text { onocrotatus }\end{array}$ & 3 & 3 & 0 & 0 & 0 & 0 & 0 & 0 \\
\hline \multirow[t]{6}{*}{ Ciconiiformes } & Phoenicopteridae & Phoenicopterus & Greater Flamingo & $\begin{array}{l}\text { Phoenicopterus } \\
\text { ruber }\end{array}$ & 109 & 103 & 0 & $2^{c}$ & $2^{c}$ & $2^{c}$ & 0 & 0 \\
\hline & & & Lesser Flamingo & $\begin{array}{l}\text { Phoenicopterus } \\
\text { minor }\end{array}$ & 5 & 5 & 0 & 0 & 0 & 0 & 0 & 0 \\
\hline & Ciconiidae & Ciconia & White Stork & Ciconia ciconia & 23 & 22 & 0 & 0 & $1^{\mathrm{a}}$ & 0 & 0 & 0 \\
\hline & & Leptoptilos & Marabou Stork & $\begin{array}{l}\text { Leptoptilos } \\
\text { crumeriiferus }\end{array}$ & 2 & 1 & $1^{b}$ & 0 & 0 & 0 & 0 & 0 \\
\hline & Threskiornithidae & Geronticus & Hermit Ibis & Geronticus eremita & 2 & 2 & 0 & 0 & 0 & 0 & 0 & 0 \\
\hline & Ardeidae & Nycticorax & $\begin{array}{l}\text { Black-crowned } \\
\text { Night Heron }\end{array}$ & Nycticorax nycticorax & 1 & 1 & 0 & 0 & 0 & 0 & 0 & 0 \\
\hline \multirow[t]{18}{*}{ Anseriformes } & Anatidae & Branta & $\begin{array}{l}\text { Red-brested } \\
\text { Goose }\end{array}$ & Branta ruficollis & 9 & 8 & 0 & 0 & $1^{b}$ & 0 & 0 & 0 \\
\hline & & & Hawaiian Goose & Branta sandvicensis & 2 & 2 & 0 & 0 & 0 & 0 & 0 & 0 \\
\hline & & Anser & $\begin{array}{l}\text { Lesser White- } \\
\text { fronted Goose }\end{array}$ & Anser erythropus & 4 & 4 & 0 & 0 & 0 & 0 & 0 & 0 \\
\hline & & & Greylag Goose & Anser anser & 1 & 1 & 0 & 0 & 0 & 0 & 0 & 0 \\
\hline & & & Domestic Goose & $\begin{array}{l}\text { Anser anser } \\
\text { domestica }\end{array}$ & 2 & 2 & 0 & 0 & 0 & 0 & 0 & 0 \\
\hline & & & Bar-headed Goose & Anser indicus & 6 & 6 & 0 & 0 & 0 & 0 & 0 & 0 \\
\hline & & Cereopsis & Cereopsis Goose & $\begin{array}{l}\text { Cereopsis } \\
\text { novaehollandiae }\end{array}$ & 3 & 3 & 0 & 0 & 0 & 0 & 0 & 0 \\
\hline & & Alopochen & Egyptian Goose & $\begin{array}{l}\text { Alopochen } \\
\text { aegyptiacus }\end{array}$ & 1 & 1 & 0 & 0 & 0 & 0 & 0 & 0 \\
\hline & & Tadorna & Ruddy Shellduck & Tadorna ferruginea & 2 & 1 & 0 & 0 & $1^{\mathrm{b}}$ & 0 & 0 & 0 \\
\hline & & Chloephaga & Magellan Goose & Chloephaga picta & 2 & 2 & 0 & 0 & 0 & 0 & 0 & 0 \\
\hline & & Dendrocygna & $\begin{array}{l}\text { Fulvous Whistling } \\
\text { Duck }\end{array}$ & Dendrocygna bicolor & 2 & 2 & 0 & 0 & 0 & 0 & 0 & 0 \\
\hline & & Tachyeres & Steamer Duck & Tachyeres pteneres & 3 & 2 & 0 & 0 & 0 & 0 & 0 & $1^{b}$ \\
\hline & & Anas & Domestic Duck & $\begin{array}{l}\text { Anas platyrhynchos } \\
\text { domesticus }\end{array}$ & 4 & 4 & 0 & 0 & 0 & 0 & 0 & 0 \\
\hline & & & Mallard & Anas platyrhynchos & 2 & 2 & 0 & 0 & 0 & 0 & 0 & 0 \\
\hline & & Aix & Wood Duck & Aix sponsa & 1 & 1 & 0 & 0 & 0 & 0 & 0 & 0 \\
\hline & & & Mandarin Duck & Aix galericulata & 1 & 1 & 0 & 0 & 0 & 0 & 0 & 0 \\
\hline & & Cygnus & Mute Swan & Cygnus olor & 1 & 1 & 0 & 0 & 0 & 0 & 0 & 0 \\
\hline & & & Tundra Swan & Cygnus columbianus & 2 & 2 & 0 & 0 & 0 & 0 & 0 & 0 \\
\hline Falconiformes & Accipitridae & Neophron & Egyptian Vulture & $\begin{array}{l}\text { Neophron } \\
\text { percnopterus }\end{array}$ & 4 & 3 & 0 & 0 & $1^{\mathrm{a}}$ & 0 & 0 & 0 \\
\hline
\end{tabular}


Table 1 Summary of the study results (Continued)

\begin{tabular}{|c|c|c|c|c|c|c|c|c|c|c|c|c|}
\hline & & Haliaeetus & White-tailed Eagle & Haliaeetus albicilla & 2 & 2 & 0 & 0 & 0 & 0 & 0 & 0 \\
\hline & & Aquila & Imperial Eagle & Aquila heliaca & 1 & 1 & 0 & 0 & 0 & 0 & 0 & 0 \\
\hline & & Circaetus & Short-toed Eagle & Circaetus gallicus & 2 & 2 & 0 & 0 & 0 & 0 & 0 & 0 \\
\hline & & Buteo & Common Buzzard & Buteo buteo & 6 & 6 & 0 & 0 & 0 & 0 & 0 & 0 \\
\hline & Pandionidae & Pandion & Osprey & Pandion haliaetus & 1 & 1 & 0 & 0 & 0 & 0 & 0 & 0 \\
\hline & Falconidae & Falco & Common Kestrel & Falco tinnunculus & 5 & 5 & 0 & 0 & 0 & 0 & 0 & 0 \\
\hline & & & Saker Falcon & Falco cherrug & 1 & 1 & 0 & 0 & 0 & 0 & 0 & 0 \\
\hline \multirow[t]{6}{*}{ Galliformes } & Phasianidae & Gallus & $\begin{array}{l}\text { Domestic } \\
\text { Chicken }\end{array}$ & $\begin{array}{l}\text { Gallus gallus } \\
\text { domesticus }\end{array}$ & 60 & 59 & 0 & 0 & 0 & 0 & 0 & $1^{\mathrm{b}}$ \\
\hline & & Lophophorus & Himalayan Monal & $\begin{array}{l}\text { Lophophorus } \\
\text { impejanus }\end{array}$ & 1 & 1 & 0 & 0 & 0 & 0 & 0 & 0 \\
\hline & & Pavo & Common Peafowl & Pavo cristatus & 9 & 9 & 0 & 0 & 0 & 0 & 0 & 0 \\
\hline & & Tragopan & Satyr Tragopan & Tragopan satyra & 1 & 1 & 0 & 0 & 0 & 0 & 0 & 0 \\
\hline & Cracidae & Crax & Great Curassow & Crax rubra & 1 & 1 & 0 & 0 & 0 & 0 & 0 & 0 \\
\hline & Meleagrididae & Meleagris & Wild Turkey & Meleagris gallopavo & 4 & 4 & 0 & 0 & 0 & 0 & 0 & 0 \\
\hline \multirow[t]{4}{*}{ Gruiformes } & Gruidae & Grus & Common Crane & Grus grus & 1 & 1 & 0 & 0 & 0 & 0 & 0 & 0 \\
\hline & & & Manchurian Crane & Grus japonensis & 1 & 1 & 0 & 0 & 0 & 0 & 0 & 0 \\
\hline & & Balearica & $\begin{array}{l}\text { Grey Crowned } \\
\text { Crane }\end{array}$ & Balearica regulorum & 2 & 2 & 0 & 0 & 0 & 0 & 0 & 0 \\
\hline & Otididae & Ardeotis & Kori Bustard & Ardeotis kori & 1 & 1 & 0 & 0 & 0 & 0 & 0 & 0 \\
\hline Charadriiformes & Burhinidae & Burhinus & Spotted Dikkop & Burhinus capensis & 1 & 1 & 0 & 0 & 0 & 0 & 0 & 0 \\
\hline \multirow[t]{2}{*}{ Columbiformes } & Columbidae & Goura & $\begin{array}{l}\text { Western Crowned } \\
\text { Pigeon }\end{array}$ & Goura cristata & 2 & 2 & 0 & 0 & 0 & 0 & 0 & 0 \\
\hline & & Columba & Domestic Pigeon & $\begin{array}{l}\text { Columba livia } \\
\text { domestica }\end{array}$ & 6 & 6 & 0 & 0 & 0 & 0 & 0 & 0 \\
\hline \multirow[t]{3}{*}{ Psittaciformes } & Psittacidae & Amazona & $\begin{array}{l}\text { White-fronted } \\
\text { Amazon }\end{array}$ & Amazona albifrons & 1 & 1 & 0 & 0 & 0 & 0 & 0 & 0 \\
\hline & & Cyanoliseus & Patagonian Conure & $\begin{array}{l}\text { Cyanoliseus } \\
\text { patagonus }\end{array}$ & 8 & 8 & 0 & 0 & 0 & 0 & 0 & 0 \\
\hline & & Ara & $\begin{array}{l}\text { Green-winged } \\
\text { Macaw }\end{array}$ & Ara chloroptera & 1 & 1 & 0 & 0 & 0 & 0 & 0 & 0 \\
\hline \multirow[t]{5}{*}{ Strigiformes } & Strigidae & Bubo & $\begin{array}{l}\text { Eurasian Eagle } \\
\text { Owl }\end{array}$ & Bubo bubo & 5 & 3 & 0 & $1^{\mathrm{a}}$ & 0 & $1^{\mathrm{a}}$ & 0 & 0 \\
\hline & & & Snowy Owl & Bubo scandiacus & 2 & 1 & 0 & $1^{\mathrm{a}}$ & 0 & 0 & 0 & 0 \\
\hline & & Asio & Long-eared Owl & Asio otus & 3 & 3 & 0 & 0 & 0 & 0 & 0 & 0 \\
\hline & & Tyto & Barn Owl & Tyto alba & 1 & 1 & 0 & 0 & 0 & 0 & 0 & 0 \\
\hline & & Strix & Ural Owl & Strix uralensis & 4 & 2 & 0 & $1^{\mathrm{a}}$ & $1^{\mathrm{a}}$ & 0 & 0 & 0 \\
\hline \multirow[t]{3}{*}{ Coraciiformes } & Halcyonidae & Dacelo & $\begin{array}{l}\text { Laughing } \\
\text { Kookaburra }\end{array}$ & $\begin{array}{l}\text { Dacelo } \\
\text { novaeguineae }\end{array}$ & 2 & 1 & 0 & 0 & 0 & $1^{b}$ & 0 & 0 \\
\hline & Meropidae & Merops & $\begin{array}{l}\text { European Bee- } \\
\text { eater }\end{array}$ & Merops apiaster & 10 & 10 & 0 & 0 & 0 & 0 & 0 & 0 \\
\hline & Coraciidae & Coracias & European Roller & Coracias garrulus & 1 & 1 & 0 & 0 & 0 & 0 & 0 & 0 \\
\hline \multirow[t]{2}{*}{ Passeriformes } & Corvidae & Corvus & Rook & Corvus frugilegus & 1 & 1 & 0 & 0 & 0 & 0 & 0 & 0 \\
\hline & & Pica & European Magpie & Pica pica & 1 & 1 & 0 & 0 & 0 & 0 & 0 & 0 \\
\hline Total & & & & & 372 & 352 & 1 & 5 & 7 & 5 & 0 & 2 \\
\hline
\end{tabular}


during essential veterinary treatment, and ii) on the occasion of Influenza A (H5N1) vaccinations of the birds. Thus, statistic-driven random sampling was not possible. Nonetheless a total number of 372 birds, belonging to 64. different species, could be included in the study.

In accordance with Meister et al. [14], the HI test proved to be a useful, cheap, host species independent and easy-to-handle screening test. Only one out of 20 sera that proved positive in the 'gold-standard' PRNT was negative in the $\mathrm{HI}$ test. On the other hand, 77 HI-positive sera must be considered non-specific for USUV, most likely due to the well-known antigenic cross-reactivity of flaviviruses $[15,16]$. WNV competitive ELISAs may also be used for a combined WNV / USUV / tick-borne encephalitis virus (TBEV) antibody screening, although these assays also show cross-reactions with other flaviviruses and thus the ELISA results must be verified by virus-specific PRNT, too [17]. Although WNV had never been observed in Switzerland and it emerged in Austria not before 2008 [18,19], i.e. 1-2 years after the sera had been collected for the present study, we tested the 20 USUV PRNT-positive sera also by PRNT-90 against WNV; only the two sera with the highest USUV antibody titers (1:640) showed neutralizing activity against WNV at the lowest dilution (1:20), which indicates low-level cross reactivity between these closely related flaviviruses.

The samples collected in the zoo of Zurich were a well-diversified cross section of many species of birds. A rather low percentage (5.3\%) of birds exhibited USUVspecific antibodies, with titers ranging between 1:20 and 1:640. The order of Anseriformes accounted for almost half of the seropositives. Interestingly, no bird of this order was USUV antigen or -nucleic acid positive during the USUV associated bird die-off in this zoo [7]. The serological results obtained indicate partial susceptibility of this avian order to USUV infection, which, however, did not result in clinical disease or death. The rather subclinical nature of USUV infection in geese was also demonstrated experimentally [20].

The samples obtained in the Vienna zoo also consisted of a wide range of avian species. With $8.75 \%$ positive results, Vienna exhibited the highest percentage of USUVspecific antibodies of all zoos studied. The titers varied from 1:40 to 1:160. Despite having the highest percentage of positives, the low to medium level of antibody titers suggests that the Vienna zoo has not been exposed to USUV in the recent past, which is supported by the fact that no USUV associated bird mortalities were recorded there since 2007. The distribution of USUV seropositives within the investigated avian species clearly indicates a higher susceptibility of birds of the order Strigiformes to USUV infection. Contrary to Anseriformes USUV invades in Strigiformes regularly the CNS, with lethal consequences. The high vulnerability of owls for USUV infection was demonstrated in several previous studies $[2,6,7,21]$. Actually, owls seem to be the second most vulnerable species of birds for the central European strain of USUV next to the Eurasian blackbird (Turdus merula).

In the zoo of Basel we did not expect evidence for USUV infection since neither in the zoo nor in the Basel area USUV associated bird mortality had been observed in the past. Surprisingly, however, $6.59 \%$ of birds tested positive for USUV antibodies by PRNT with titers ranging from 1:40 to 1:160. All positive birds were greater flamingos (6 out of 80 tested greater flamingos). None of the flamingos, however, had shown overt signs of disease, or had died. Flamingos seem to be in general susceptible to certain flavivirus infections, as evidenced for WNV on the occasion of the emergence of this virus in the U.S. [13]. On the other hand, USUV antibody positive birds in the absence of overt disease resembles the USUV and WNV epidemiology in birds reported for the U.K. by Buckley et al. [22]. Since in the zoo of Basel only very few other avian species could be investigated, no statement can be made regarding the susceptibility to USUV for other species of birds.

In the Budapest zoo 68 birds of 28 species belonging to 11 orders were tested, but none of them exhibited detectable USUV antibodies. USUV associated bird mortality had not been observed in this zoo, in the city of Budapest and its surroundings, however, limited blackbird mortality was attributed to USUV infection [5]. Most likely, the birds in Budapest zoo were not exposed to USUV.

Despite the limitations in sampling it was possible to investigate serum samples of 372 birds, belonging to 64 species, kept in captivity in 4 different zoos in 3 central European countries. This is the first survey for USUVspecific antibodies in mostly exotic species of birds kept in zoos in or close to USUV-endemic areas.

One of the surprising outcomes of this study was a much lower USUV antibody prevalence than expected, which is in contrast to a similar investigation carried out on certain wild bird species [14]. It seems that only a rather small proportion of exotic bird species is susceptible to USUV infection, which is actually good news for zoological gardens.

Summarizing the current literature, the most vulnerable species of birds for the central European strain of USUV remains to be the Eurasian blackbird $[2-10,21]$, followed by different species of owls $[2,6,7,21$, this study] and the house sparrow $[3,7,21]$. Besides the above species, single cases of USUV associated mortality were reported from a variety of other songbird species [3,4], especially within the order Passeriformes. 


\section{Conclusions}

The present investigations did not reveal high USUV vulnerability of any other major order or species of birds besides those already known. On the other hand, the high susceptibility of owls (Strigiformes) to USUV infection is strongly supported by the present study, which actually parallels observations on WNV $[23,24]$. We also expected the order of Falconiformes to be more affected by USUV but did not obtain enough evidence to support this hypothesis.

Based on our study and the absence of converse reports we can conclude that USUV seems not to pose an imminent threat to zoo bird populations in central Europe at the moment. Depending on a variety of especially environmental factors, however, this situation may change at any time in the (near) future, as experienced with WNV. It is therefore strongly suggested to continue the combined WNV and USUV surveillance activities in the affected areas.

\section{Methods}

Bird sera were collected in the zoos of Basel, Budapest, Vienna, and Zurich between October 2006 and August 2007. In total, sera of 372 zoo-birds, belonging to 15 different orders (142 Ciconiiformes, 78 Galliformes, 48 Anseriformes, 22 Falconiformes, 20 Sphenisciformes, 19 Columbiformes, 15 Strigiformes, 13 Coraciiformes, 10 Psittaciformes, 8 Pelicaniformes, 5 Gruiformes, 2 Passe riformes, 1 Casuariformes, 1 Choradriiformes, 1 Rheifor mes), 25 families, 51 genera, and 64 species were investigated (Table 1). One hundred and thirty two samples were collected at the zoological garden in Zurich, 80 samples at the zoo in Vienna, 91 specimens at the Basel zoo and 68 samples at the Budapest zoo. In Zurich and Basel blood was taken on the occasion of Influenza A ( $\mathrm{H} 5 \mathrm{~N} 1)$ vaccinations, whereas in Vienna and Budapest samples were obtained only from birds that were examined because of injuries or during other investigations. All tested birds except 18 greater flamingos (Phoeni copterus ruber) from Basel zoo were older than one year. The majority of investigated birds at Basel zoo were greater flamingos (80 out of 91).

In all cases between 0.3 and $1.0 \mathrm{ml}$ of blood was drawn from the cutaneous ulnar vein, the jugular vein or a vein on the leg. The blood was centrifuged at 2000 $\times \mathrm{g}$ for $10 \mathrm{~min}$. The serum was separated from the clot and stored at $-20^{\circ} \mathrm{C}$ until investigated. The serum samples were inactivated at $56^{\circ} \mathrm{C}$ for $30 \mathrm{~min}$ before analyses. In order to obtain information about sensitivity and specificity of the easy-to-perform HI test, each serum was submitted to two different assays: an $\mathrm{HI}$ test and an USUV-specific PRNT-90, the "gold standard" in flavivirus serology.

\section{HI test}

The HI test was conducted as described by Clarke and Casals [25]. First, non-specific inhibitors were bound and removed by kaolin treatment, followed by an isoagglutinin treatment through adsorption with $1 \%$ goose erythrocytes. Then, $25 \mu \mathrm{l}$ serum was mixed with $25 \mu \mathrm{l}$ [= 8 hemagglutination (HA) units] of USUV antigen (strain Vienna 2001 [26]) and transferred into U-shaped microtiter plates. The HI titer was defined as the highest serum dilution that caused complete inhibition of erythrocyte agglutination by 8 HA units of viral antigen. A titer of $\geq 1: 20$ was considered positive.

\section{PRNT-90}

The PRNT was carried out as described by De Madrid and Porterfield [16], modified to a microtechnique [27]. The procedure was run in flat-bottomed, 96-well microplates. The inactivated sera were mixed with $30 \mu \mathrm{l}$ of virus suspension (USUV strain Vienna 2001 [26]), incubated at $37^{\circ} \mathrm{C}$ for $60 \mathrm{~min}$ and then supplemented with 60 $\mu \mathrm{l}$ of cell suspension (porcine kidney cells in Minimal Essential Medium with 3\% fetal calf serum). After an incubation period of 4 hours at $37^{\circ} \mathrm{C}, 120 \mu \mathrm{l}$ of carboxy-methyl cellulose overlay was added to each well and further incubated at $37^{\circ} \mathrm{C}$. After 3 days the fluid was removed and 150 $\mu \mathrm{l}$ of a coloring agent (naphtol blue black solution) was added and incubated for $40 \mathrm{~min}$ at room temperature. The PRNT titer was defined as the highest serum dilution with an at least $90 \%$ reduction of the number of plaques. A titer of $\geq 1: 20$ was regarded positive.

The PRNT-90 against WNV was carried out as described above for USUV, but with WNV strain Eg101 [17].

\section{Competing interests}

None of the authors of this paper has a financial or personal relationship with other people or organizations that could inappropriately influence or bias the content of the paper. The authors declare that they have no competing interests.

\section{Authors' contributions}

NB carried out all the experimental work and drafted the manuscript. WZ, CW, HWS and ES assisted in the blood draws and provided valuable information on the birds and the zoos, respectively. HL carried out the laboratory tests. NN coordinated and supervised the study and revised the manuscript. All authors read and approved the final manuscript.

\section{Acknowledgements}

This study was partially supported by the European Union grants HEALTH.2010.2.3.3-3 Project 261391 EuroWestNile (http://www.eurowestnile. org/) and FP7-261504 EDENext and is catalogued by the EDENext Steering Committee as EDENext166 (www.edenext.eu). The authors would like to thank Prof. Tamas Bakonyi, Dr. Ulrike Eulenberger, Dr. Maria Furger, Prof. Jean-Michel Hatt, Dr. Katharina Reitl, Dr. Hanna Vielgrader, Dr. Thomas Voracek and Prof. Herbert Weissenböck for their assistance in the performance of the investigations and for valuable discussions.

\section{Author details}

${ }^{1}$ Viral Zoonoses, Emerging and Vector-Borne Infections Group, Institute of Virology, University of Veterinary Medicine Vienna, Vienna, Austria. ${ }^{2}$ Vienna Zoo Schönbrunn, Vienna, Austria. ${ }^{3}$ Basel Zoo, Basel, Switzerland. ${ }^{4}$ Clinic for Zoo Animals, Exotic Pets and Wildlife, Vetsuisse Faculty, University of Zurich, 
Zurich, Switzerland. ${ }^{5}$ Budapest Zoo, Budapest, Hungary. ${ }^{6}$ Department of Microbiology and Immunology, College of Medicine and Health Sciences, Sultan Qaboos University, Muscat, Oman. ${ }^{7}$ Kleintierklinik Breitensee, Vienna, Austria. ${ }^{8}$ Tierarztpraxis Neuwiesen, Uster, Switzerland. ${ }^{9}$ Knies Kinderzoo, Rapperswil, Switzerland.

Received: 9 June 2013 Accepted: 5 August 2013

Published: 6 August 2013

\section{References}

1. Woodall JP: The viruses isolated from arthropods at the East African Virus Research Institute in the 26 years ending December 1963. Proc E Afr Acad 1964, 2:141-146.

2. Weissenböck H, Kolodziejek J, Url A, Lussy H, Rebel-Bauder B, Nowotny N: Emergence of Usutu virus, an African mosquito-borne flavivirus of the Japanese encephalitis virus group, central Europe. Emerg Infect Dis 2002, 8:652-656.

3. Weissenböck H, Kolodziejek J, Fragner K, Kuhn R, Pfeffer M, Nowotny N: Usutu virus activity in Austria, 2001-2002. Microbes Infect 2003, 5:1132-1136.

4. Chvala S, Bakonyi T, Bukovsky C, Meister T, Brugger K, Rubel F, Nowotny N, Weissenböck H: Monitoring of Usutu virus activity and spread by using dead bird surveillance in Austria, 2003-2005. Vet Microbiol 2007, 122:237-245.

5. Bakonyi T, Erdélyi K, Ursu K, Ferenczi E, Csörgő T, Lussy H, Chvala S, Bukovsky C, Meister T, Weissenböck H, Nowotny N: Emergence of Usutu Virus in Hungary. J Clin Microbiol 2007, 45:3870-3874.

6. Manarolla G, Bakonyi T, Gallazzi D, Crosta L, Weissenböck H, Dorrestein GM Nowotny N: Usutu virus in wild birds in northern Italy. Vet Microbiol 2010, 141:159-163.

7. Steinmetz HW, Bakonyi T, Weissenböck H, Hatt J-M, Eulenberger U, Robert N, Hoop R, Nowotny N: Emergence and establishment of Usutu virus infection in wild and captive avian species in and around Zurich, Switzerland-genomic and pathologic comparison to other central European outbreaks. Vet Microbiol 2011, 148:207-212.

8. Becker $N$, Jöst $H$, Ziegler $U$, Eiden $M$, Höper $D$, Emmerich $P$, Fichet-Calvet $E$, Ehichioya DU, Czajka C, Gabriel M, Hoffmann B, Beer M, Tenner-Racz K, Racz P, Günther S, Wink M, Bosch S, Konrad A, Pfeffer M, Groschup MH, SchmidtChanasit J: Epizootic emergence of Usutu virus in wild and captive birds in Germany. PLoS One 2012, 7(2):e32604.

9. Hubálek Z, Rudolf I, Capek M, Bakonyi T, Betášová L, Nowotny N: Usutu virus in blackbirds (Turdus merula), Czech Republic, 2011-2012. Transbound Emerg Dis 2012. doi:10.1111/tbed.12025. [Epub ahead of print].

10. Weissenböck H, Bakonyi T, Rossi G, Mani P, Nowotny N: Usutu virus, Italy, 1996. Emerg Infect Dis 2013, 19:274-277.

11. Pecorari M, Longo G, Gennari W, Grottola A, Sabbatini A, Tagliazucchi S, Savini G, Monaco F, Simone M, Lelli R, Rumpianesi F: First human case of Usutu virus neuroinvasive infection, Italy, August-September 2009. Euro Surveill 2009, 14(50):19446.

12. Cavrini F, Gaibani P, Longo G, Pierro AM, Rossini G, Bonilauri P, Gerundi GE, Di Benedetto F, Pasetto A, Girardis M, Dottori M, Landini MP, Sambri V: Usutu virus infection in a patient who underwent orthotropic liver transplantation, Italy, August-September 2009. Euro Surveill 2009, 14(50):19448.

13. Lanciotti RS, Roehrig JT, Deubel V, Smith J, Parker M, Steele K, Crise B, Volpe KE, Crabtree MB, Scherret JH, Hall RA, Mackenzie JS, Cropp CB, Panigrahy B, Ostlund E, Schmitt B, Malkinson M, Banet C, Weissman J, Komar N, Savage HM, Stone W, McNamara T, Gubler DJ: Origin of the West Nile virus responsible for an outbreak of encephalitis in the northeastern United States. Science 1999, 286:2333-2337.

14. Meister T, Lussy H, Bakonyi T, Sikutova S, Rudolf I, Vogl W, Winkler H, Frey H, Hubalek Z, Nowotny N, Weissenböck H: Serological evidence of continuing high Usutu virus activity and establishment of herd immunity in wild birds in Austria. Vet Microbiol 2008, 127:237-248.

15. Casals J, Brown LV: Hemagglutination with arthropod-borne viruses. $J$ Exp Med 1954, 99:429-449.

16. De Madrid AT, Porterfield JS: The flaviviruses (group B arboviruses): a cross-neutralisation study. J Gen Virol 1974, 23:91-96.

17. Rushton JO, Lecollinet S, Hubálek Z, Svobodová P, Lussy H, Nowotny N: Tick-borne encephalitis virus in horses, Austria, 2011. Emerg Infect Dis 2013, 19:635-637.

18. Wodak E, Richter S, Bagó Z, Revilla-Fernández S, Weissenböck H, Nowotny $\mathrm{N}$, Winter P: Detection and molecular analysis of West Nile virus infections in birds of prey in the eastern part of Austria in 2008 and 2009. Vet Microbiol 2011, 149:358-366.

19. Bakonyi T, Ferenczi E, Erdélyi K, Kutasi O, Csörgő T, Seidel B, Weissenböck H, Brugger K, Bán E, Nowotny N: Explosive spread of a neuroinvasive lineage 2 West Nile virus in Central Europe, 2008/2009. Vet Microbiol 2013, 165:61-70.

20. Chvala S, Bakonyi T, Hackl R, Hess M, Nowotny N, Weissenböck H: Limited pathogenicity of Usutu virus for the domestic goose (Anser anser $f$. domestica) following experimental inoculation. J Vet Med B Infect Dis Vet Public Health 2006, 53:171-175.

21. Chvala S, Kolodziejek J, Nowotny N, Weissenböck H: Pathology and viral distribution in fatal Usutu virus infections of birds from the 2001 and 2002 outbreaks in Austria. J Comp Path 2004, 131:176-185.

22. Buckley A, Dawson A, Moss SR, Hinsley SA, Bellamy PE, Gould EA: Serological evidence of West Nile virus, Usutu virus and Sindbis virus infection of birds in the UK. J Gen Virol 2003, 84:2807-2817.

23. Fitzgerald SD, Patterson JS, Kiupel M, Simmons HA, Grimes SD, Sarver CF Fulton RM, Steficek BA, Cooley TM, Massey JP, Sikarskie JG: Clinical and pathologic features of West Nile virus infection in native North American owls (Familiy Strigidae). Avian Dis 2003, 47:602-610.

24. Gancz AY, Barker IK, Lindsay R, Dibernardo A, McKeever K, Hunter B: West Nile virus outbreak in North American owls. Emerg Infect Dis 2004, 10:2135-2142

25. Clarke DH, Casals J: Techniques for hemagglutination and hemagglutination-inhibition with arthropod-borne viruses. Am J Trop Med Hyg 1958, 7:561-573.

26. Bakonyi T, Gould EA, Kolodziejek J, Weissenböck H, Nowotny N: Complete genome analysis and molecular characterization of Usutu virus that emerged in Austria in 2001: comparison with the South African strain SAAR-1776 and other flaviviruses. Virology 2004, 328:301-310.

27. Hubálek Z, Chanas AC, Johnson BK, Simpson DIH: Cross-neutalization study of seven California group (Bunyaviridae) strains in homoiothermous (PS) and poikilothermous (XTC-2) vertebrate cells. J Gen Virol 1979, 42:357-362.

doi:10.1186/1746-6148-9-153

Cite this article as: Buchebner et al:: Low Usutu virus seroprevalence in four zoological gardens in central Europe. BMC Veterinary Research 2013 9:153.

\section{Submit your next manuscript to BioMed Central and take full advantage of:}

- Convenient online submission

- Thorough peer review

- No space constraints or color figure charges

- Immediate publication on acceptance

- Inclusion in PubMed, CAS, Scopus and Google Scholar

- Research which is freely available for redistribution 